\title{
PHILOSOPHICAL SUFISM: AN ANALYSIS OF SUHRAWARDĪ'S CONTRIBUTION WITH SPECIAL REFERENCE TO HIS SCHOOL OF ILLUMINATION (ISHR $\bar{A} Q \bar{I})$
}

\section{Muhammad Obaidullah}

School of Islamic Studies, Manarat International University. Dhaka-1216. Bangladesh.

Email: obaidiub@yahoo.com

\begin{abstract}
Khulasah
Kajian ini bertujuan menjelaskan falsafah mistik Shihāb al-Dīn Yahya Suhrawardi (1154-1191), seorang ahli falsafah mistik dan pengasas aliran iluminasi (Ishrāqi), yang dikenali umum sebagai Shaykh al-Ishrāqi. Kertas ini juga menjelaskan asalusul teori iluminasi (Ishrāqi) , ciri-ciri dan peranannya dalam pemikiran sufi falsafi. Kesimpulannya, doktrin ini sangat diperlukan pada masa kini bagi memulih dan menyucikan jiwa kita untuk meraih kejayaan di dunia dan akhirat. Metodologi yang digunakan dalam kajian ini adalah bersifat kritikal dan analitikal.
\end{abstract}

Kata Kunci: Iluminasi; sufisme; falsafah; epistemologi; kosmologi; ontologi.

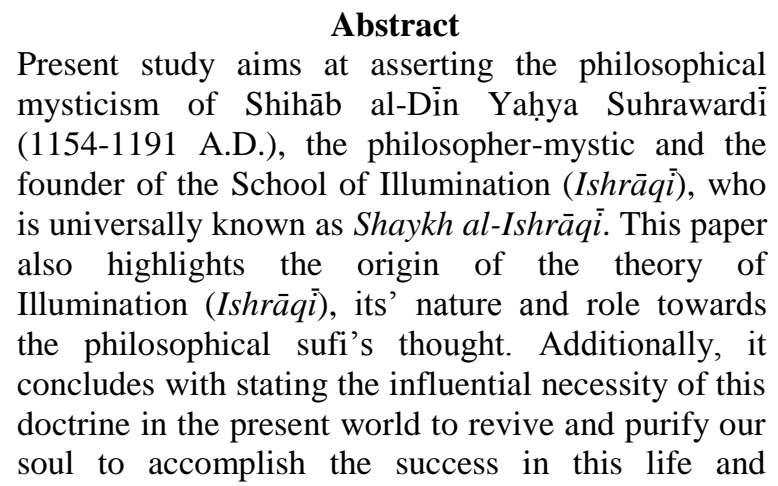


hereafter with the critical evaluation of others. The methodologies applied in the study are critical and analytical.

Keywords: Illumination; Sufism; philosophy; epistemology; cosmology; ontology.

\section{Introduction}

Suhrawardi's (d. 1191) contribution towards development of Islamic mysticism and mystical philosophy with special reference to his school of illumination is discussed, analyzed and appreciated by scholars, thinkers, scholars and others. His intellectual contributions and of the impact he had on his successors, in particular later Islamic philosophy which culminated in the "School of Isfahan'" are also mentionable. The present work undertakes a study of the mystical dimension of Suhrawardi's thought. Like many others, Suhrawardi (d. 1191) build up a system as well as he commended on various traditional philosophical topics such as metaphysics,${ }^{2}$ ontology, ${ }^{3}$ cosmology, ${ }^{4}$ and

${ }^{1}$ The founder of this School is Mir Muhammad Baqir Damad Husayni Astarabadi, known as 'Mir Damad', was one of the most outstanding figures of this period. See more on School of Isfahan, Mehdi Amin Razavi, Suhrawardi and the School of Illumination (Surrey: Curzon Press, 1997), 124-128.

${ }^{2}$ Metaphysics is the branch of philosophy concerned with the nature of ultimate reality. Metaphysics is customarily divided into ontology, which deals with the question of how many fundamentally distinct sorts of entities compose the universe, and metaphysics proper, which is concerned with describing the most general traits of reality.. See for details, Donald M Borchert. (ed.), Encyclopedia of Philosophy, $2^{\text {nd }}$ ed. (United State of America: Thomson Gale, 2006), vol. $6,169$.

${ }^{3}$ In philosophy, ontology is the study of the nature of being, existence, or reality in general and of its basic categories and their relations. Traditionally listed as part of a major branch of philosophy known as metaphysics, ontology gives particular emphasis to questions regarding what entities exist or can be said to exist, and how such entities can be grouped and related within a hierarchy, subdivided according to similarities and differences. See for details, Borchert, Encyclopedia of Philosophy, vol. 7, 21-22. 
epistemology ${ }^{5}$. His thought later on considered as the school of Illumination or School of al-Ishrāqi is one of the most significant schools in Islamic mystical philosophy. This paper basically introduces Suhraward $\bar{i}$ and his contribution. In this regard, his concept of Illumination (Ishrāqi) has been emphasized more in the discussion rather than any other of his thoughts.

\section{A Biographical Sketch of Suhrawardī (1154-1191 A.D.) and His Works}

\section{Suhrawardī (d. 1191): The Master of Șūfí Ishrāqī}

Suhrawardi's fill name is Shihāb al-Dīn Yahya ibn Habash ibn Amirak Abū al-Futūh Suhrawardī al-Maqtūl. He is considered as the 'master of illumination' (Shaykh alIshrāqi). He was born in Aleppo, Syria, in 1154 and was killed by order of Saladin in 1191. ${ }^{6}$ He started his education in nearby Maraghah with the loves of Majd alDin al-Jili, one of the teachers of Fakhr al-Din al-Rāzi

${ }^{4}$ Cosmology is study of the universe in its totality, and by extension, humanity's place in it. The study of the universe has a long history involving science, philosophy, esotericism, and religion. See for details Ibid., vol. 2, 556-557.

${ }^{5}$ Epistemology attempts to explain the nature and scope of knowledge and rational belief. Its purview also includes formulating and assessing arguments for skeptical conclusions that we do not have knowledge of various kinds. In addition, epistemologists address topics that are closely related to these core concerns, including evaluations of thought processes and the relationship of science to philosophy. Ibid., vol. 3, 270.

6 Majid Fakhry, Islamic Philosophy, Theology and Mysticism (Oxford: Oneworld Publications, 1977), 113. Some writers mention that he was born in the northwestern Iranian village of "Suhrawardi" located in Kurdish in 1155 (See: Butterworth, C. E., The Political Aspects of Islamic Philosophy: Essays in Honor of Muhsin S. Mahdi (Cambridge: Harvard University Press, 1992), 336) inhabited region in present-day northwestern Iran and was executed at age of 36 or 38 in 1191 in Aleppo. Suhraward or Suhrabard was a Kurdish village located between present-day towns of Zanjan and Bijar. See: M. Kamil, Mulla Sadr's Transcendent Philosophy (England: Ashgate Publishing Inc. 2006), 136. 
(d.1209). He then traveled to Isfahān, where he studied with the logician Zahir al-Farisi with whom he read a text on logic written by Ibn Sahlan al-Sawi (d. 1170). Suhrawardi then embarked on a journey that led him to Anatolia. Shams al-Dīn al-Shahrazūri (d.1288) identifies this period as his quest for spiritual guidance, a period when he would have met a number of sufi masters, such as Fakhr al-Dīn al-Maridini (d.1198), and would have sought patrons among the local rulers of Anatolia. ${ }^{7}$

Once Suhrawardi arrived in Aleppo in 1183, the year Saladin (d.1193) conquered that city and handed it over to his son al-Zāhir (d.1216), he made a name for himself among religious scholars of the city, like Iftikhār al-Dīn and others. In 1186, at the age of thirty-three, he completed his most significant and famous work titled the Philosophy of Illumination.

\section{Suhrawardī's Contribution to Knowledge}

Suhrawardi wrote some books and treaties which contribute a lot in the field of knowledge, especially in the field of philosophical mysticism. Suhrawardi's works have been classified into five different categories which are as follows: ${ }^{8}$

i. Treatise

Al-Talwihhàt (The Book of Intimations), al-Muqāwamāt (The Book of Opposites), al-Muțārahāt (The Book of Conversations), and finally Hikmah al-Ishrāq (The Philosophy of Illumination) have been classified and

7 Ibid.

8 For more information on S.H. Nasr's classification, see: Three Muslim Sages (Cambridge: Cambridge University Press, 1973), 58. For H. Corbin's classification see his "Prolegomena Instruct" to Suhrawardi: Opera Metaphysica et Mystica, vol. 16, (Istanbul: Bibliotheca Islamica, 1945), 16. As quoted by Razavi, Mehdi Amin "The Significance of Suhrawardi's Persian Sufi Writings in the Philosophy of Illumination", in The Heritage of Sufism: Classical Persian Sufism from its Origins to Rumi (700-1300), ed. Leonard Lewisohn (Oxford: Oneworld Publications, 1999), vol. 1, 261. 
considered as the treatises of a philosophical nature. The first three of these works were written in the tradition of the peripatetic ${ }^{9}$ although there are criticisms of certain peripatetic thinkers on them.

9 The term 'peripatetic' is a transliteration of the ancient Greek word peripatetikos, which means 'of walking' or 'given to walking about', or 'going from place to place'. Sally Wehmeier ed., Oxford Advanced Learner's Dictionary to Current English (New York: Oxford University Press, 2000), 865. The peripatetics were members of a school of philosophy in ancient Greece. Their teachings derived from their founder, the Greek philosopher Aristotle (d. 322 B.C.E) and peripatetic is a name given to his followers. The name 'Peripatetic' came from Aristotle's alleged habit of walking while lecturing. See: G.W.F. Hegel, Lectures on the History of Philosophy 1825-1826: Greek Philosophy, 2, ed. Robert F. Brown, (United Kingdom: Oxford University Press, 2006), 229. The main teaching of this school, according to Aristotle (d. 322 B.C.E.), is philosophy means science, and its aim is the recognition of the 'why' in all things. All change or motion takes place in regard to substance, quantity, quality and place. There are three kinds of substances those alternately in motion and at rest, as the animals; those perpetually in motion, as the sky; and those eternally stationary. The last, in them immovable and imperishable, are the source and origin of all motion. Among them there must be one first being, unchangeable, which acts without the intervention of any other being. All that is proceeds from it; it is the most perfect intelligence God. The immediate action of this prime mover - happy in the contemplation of itself - extends only to the heavens; the other inferior spheres are moved by other incorporeal and eternal substances, which the popular belief adores as gods. The heavens are of a more perfect and divine nature than other bodies. In the centre of the universe is the earth, round and stationary. The stars, like the sky, beings of a higher nature, but of grosser matter, move by the impulse of the prime mover. Additionally, for Aristotle, matter is the basis of all that exists; it comprises the potentiality of everything, but of itself is not actually anything. A determinate thing only comes into being when the potentiality in matter is converted into actuality. This is achieved by form, the idea existent not as one outside the many, but as one in the many, the completion of the potentiality latent in the matter. Another teaching of this school is the soul is the principle of life in the organic body, and is inseparable from the body. See for details: Robert Audi, The Cambridge Dictionary of Philosophy (United Kingdom: Cambridge University Press, 1999), 659-660. 


\section{ii. Shorter Works}

There are also some shorter works, some of which are also of a doctrinal nature. These are: Hayākil al-Nūr (Temples of Light ${ }^{10}$ ), Alwāh al-'Imādiyyah (The Tablets of 'Imād al-Dīn), Partaw-nama (Treatise on Illumination), $F \bar{i}$ 'Itiqād al-Hukamā' (On the Faith of the Adepts), alLamahat (Flashes of Light), Yazdanshinakht (Knowledge of the Divine), and Bustān al-Qulüb (The Garden of the Heart). Some of these works are in Arabic and some in Persian. His works in Persian are among the finest literary writings in the Persian language. Suhrawardi (d. 1191) himself may have translated some of these treatises from Arabic into Persian.

iii. Treatises of Exotic Nature in Persian

These are initiatory narratives which contain a highly symbolic language, most of which incorporate 'Zoroastrian' and 'Hermetic' symbols as well as Islamic ones. These treatises include: 'Aql-i surkh (The Red Intellect), Awaz-i par-i Jibra'il (The Chant of the Wing of Gabriel), al-Qișsah al-Ghurbāt al-Gharbiyyah (Recital of the Occidental Exile), Lughat-i muran (Language of the Termites), Risālah fi Halah al-Tufuliyyah (Treatise on the State of Childhood), Ruzi ba jama'at-i sufiyan (A Day among the Community of the Sufis), Safir-i simurg (The Song of the Griffin), and Risālah fí al-Mi rāj (Treatise on the Nocturnal Journey). These treatises are intended to demonstrate the journey of the soul toward unity and the inherent yearning of man toward gnosis (ma`rifah). As will be seen, without the help of the above works Ishrāqi doctrine cannot be fully understood.

iv. Treatises of a Philosophic and Initiatic Nature There are also a number of treatises of a philosophic and initiatic nature. These include his translation of Risālah al-

${ }^{10}$ This book is translated into English which was edited by M.A. Abi Rayyan and published by Al-Maktabah al-Tijāriyyah al-Kubrā, Cairo in 1957. 
Tayr (Treatise of the Birds) of Ibn Sinā (d. 1037) and the commentary in Persian upon Ibn Sinā's al-Ishārāt wa alTanbihāt. There is also his treatise Risālah fi Haqiqah al'Ishq (Treatise on the Reality of Love) which is based on Ibn Sīnā's Risālah fï al-'Ishq (Treatise on Love) and his commentaries on verses of the Qur'an and the Hadith. It is also said that Suhrawardi may have written a commentary upon the Fuṣuṣ of al-Farābi, which has been lost. ${ }^{11}$

v. Liturgical Writings

Finally, there is the category of his liturgical writings, namely prayers, invocations and litanies. Shahrazuri calls them al-Waridah wa al-Taqdīsāt ${ }^{12}$ (Invocations and Prayers). ${ }^{13}$ Despite certain extracts which appear in Henry Corbin's L'Archange empourpre, these important writings of Suhrawardi have received the least amount of attention. They are of a liturgical nature and represent Suhrawardi's angelology and its relationship to the spiritual entities of the planets.

Suhrawardi's works circulated mainly within the traditional philosophical circles of learning of the Islamic East until the end of the $19^{\text {th }}$ and the beginning of the $20^{\text {th }}$ centuries. Later his all books are translated into many languages.

\section{Suhrawardī and the Philosophical Sufism}

\section{Suhrawardī's Concept of Light}

Suhrawardi, in his Philosophy of Illumination, developed a truly original light ontology. While light always remains in itself identical, its proximity or distance from 'the Light of Lights' determines the ontic light reality of all beings. Light operates through the activities of dominion of the

\footnotetext{
11 Nasr, Three Muslim Sages, 150.

12 The invocations and prayers have been published in M. Mu'in (ed.), Majala-yi amuzish wa parvarish (Tehran: Ministry of Education Press, 1924), 5.

13 Nasr, Three Muslim Sages, 150.
} 
higher 'triumphal' or 'victorial' lights, as well as the desire of the lower lights for the higher ones, operating at all levels and hierarchies of reality. ${ }^{14}$ According to him, the core of the 'wisdom of illumination' is the 'science of light', which deals with the nature of light and the manner of its fusion. This light is indefinable, because it is the most manifest reality; it is indeed the reality which 'manifests' all other things and is the substance that enters into the composition of all other substances, material or immaterial. ${ }^{15}$

Light, in the view of Suhrawardi, is divided into two such as; (1) light of itself and in itself, and; (2) light of itself but in another. It is latter light that illuminates all things; but whether in itself or in another, light is supremely manifest and is the cause of the manifestation all things which actually emanate from it. It follows, therefore, that is living, since life is nothing but the essential self-manifestation outwardly on other things. ${ }^{16}$

Furthermore, there are another three lights in the view of Suhrawardi which are described by Majid Fakhry in his book. That is why I would like to quote his words here. He states that:

"... in addition to necessity, the Light of Lights is characterized by unity. For if we posit two primary lights, we would be involved in this contradiction, that they must derive their being from a third light, which is entirely one. Similarly, it is characterized by the capacity to import its light to all the secondary lights emanation from it. The first of these lights is called by Suhrawardi the First Light, which

14 J.Walbridge, The Leaven of the Ancients: Suhrawardi and the Heritage of the Greeks (Albany: State University of New York Press, 2000), 24.

15 Majid Fakhry, Islamic Philosophy, Theology and Mysticism (Oxford: Oneworld Publications, 1977), 114.

${ }^{16}$ See for detail, Ibid., 115. 
differs from its source or the Light of Lights only in the degree of its perfection or purity. Next, from the First Light emanate the secondary lights, the heavenly bodies and the physical compounds or elements making up the physical world, to which Suhrawardi applies the name 'isthmuses'. This latter world may also be described as the shadow of the Light of Lights or its penumbra and like its source or cause is eternal". ${ }^{17}$

In summary, it is very complicated to show the view of Illuminationist philosophy. Because Suhrawardi uses various term to depict the level of light. For example, he uses the term "The Self-Subsisting Light, The Holy Light, The Necessary Being, The Pure Light to describe the Light of Light which is the source of all Lights. So that, after above discussion, we can conclude to state that 'the Light of Light' is God and all other things manifest from this Light of Light means this is the source of other lights. According to Suhrawardi, there are many lights levels according to their perfection. The lowest level of these lights is darkness, in Suhrawardi's view, the body without soul, light. In this matter, he uses the term 'isfandar mood', whose talisman is earth or dust, to state the elemental combination of the physical objects.

The most perfection mood of elemental combinations is the humankind, who receive their perfection from Gabriel and this is the Holy Spirit, which breathes into the humankind the human spirit, called 'the Isfahbad of humanity', according to Suhrawardi's view. Moreover, everything other than pure light consists both of that which requires a bearer and is called the 'dark substance', or the form of that substance, which is darkness itself. He uses the term 'isthmuses' (Barzakh) which are pure

${ }^{17}$ Ibid. 
darkness and receive all the light permeating them from an outside source. It is also mentionable to state that the nature of the soul is to return to the world of Pure Light. ${ }^{18}$

\section{The Origin of Suhrawardī's Concept of Light}

It is difficult to find out the exact origin of Suhrawardi's concept of light while his philosophy of Illumination is not based on any particular idea or philosophy. It is seemed that the philosophy of Illumination is related to many ideas, i.e. to the Platonic philosophy, Peripatetic school and so on. To depict the origin of the Suhrawardi's concept of light, according to my opinion, it is necessary to discuss the historical background of using light in philosophy including epistemology, ontology, physics, metaphysics, and so on. Consequently, in this passage, we are going to discuss on the light used in any philosophy before Suhraward $\bar{i}$ (d. 1191) from the historical background.

In discussion of the concept of light or the philosophy of Illumination some ancient ides come to show their relation to this concept such as the philosophy of Plato (d.347 B.C.E.), the philosophy of Aristotle (d.322 B.C.E.), the philosophy of Ibn Sīnā (d.1037) and the Ghazāli's (d.1111) discussion on the ontology of light in the Qur'an in his works Mishkāt al-Anwār (The Niche for Light). Therefore we are going to discuss on these philosophies and their relation to the Suhrawardi's concept of light in brief.

In Plato's philosophy, light is used as an example to describe the cosmology, epistemology and other philosophical issues. In cosmology, according to the philosophy of Plato, the physical objects and physical events are 'shadows' of their ideal or perfect forms, and exist only to the extent that they instantiate the perfect versions of themselves. While he used the word 'shadow'

\footnotetext{
${ }^{18}$ Fakhry, Islamic Philosophy, Theology and Mysticism, 115.
} 
to describe the physical world, the perfect form of this world is pure light. The shadows, as an example, which he uses in 'the allegory of the Cave' ${ }^{19}$ to illustrate our nature in its education and want of education. Obviously, it has link to his doctrine of "the forms". ${ }^{20}$ Moreover, in his description of the pure land, he uses the term "the true light" as he states: ${ }^{21}$

"But the true earth is pure and situated in the pure heaven... and it is the heaven which is commonly spoken by us as the ether... for if any man could arrive at the extreme limit... he would acknowledge that this other world was

19 The Allegory of the Cave is an allegory used by the Greek philosopher Plato (d. 347 B.C.E) in his work The Republic to illustrate 'our nature in its education and want of education'. The allegory of the cave is written as a fictional dialogue between Plato's teacher Socrates (d. 399 B.C.E.) and Plato's brother Glaucon. Plato imagines a group of people who have lived chained in a cave all of their lives, facing a blank wall. The people watch shadows projected on the wall by things passing in front of the cave entrance, and begin to ascribe forms to these shadows. According to Plato, the shadows are as close as the prisoners get to seeing reality. He then explains how the philosopher is like a prisoner who is freed from the cave and comes to understand that the shadows on the wall are not constitutive of reality at all, as he can perceive the true form of reality rather than the mere shadows seen by the prisoners. The allegory is related to Plato's theory of forms. In addition, the allegory of the cave is an attempt to explain the philosopher's place in society. See for details, Charles H. Khan, Plato and the Socratic Dialogue: The Philosophical use of a Literary Form (United Kingdom: Cambridge University Press, 2004), 125-133.

${ }^{20}$ Plato's Theory of Forms asserts that forms (or ideas), and not the material world of change known to us through sensation, possess the highest and most fundamental kind of reality. The forms are the only true objects of study that can provide us with genuine knowledge. Plato spoke of forms in formulating his solution to the problem of universals. See for details, Stephen Watt, Introduction: the theory of forms (London: Wordsworth edition, 1997), 114-116.

${ }^{21}$ As quoted by Martha C. Back, Plato's Self-Corrective Development of the Concepts of Soul, Form and Immortality in Three Arguments of the Pheado (United Kingdom: Edwin Mellon Press, 1999), 148. 
the place of the true heaven, and the true light and the true earth."

Additionally, in the The Republic, Plato uses the sun as a metaphor for the source of "intellectual illumination", which he holds to be "The Form of the Good". ${ }^{22} \mathrm{He}$ also states that the strongest and the best source of light is the sun..$^{23}$ And everything is the illuminated by the highest of the Forms, that of the Good. ${ }^{24}$

Likewise, in the philosophy of Aristotle, the notion of light is also discussed. But it is not more than his teacher. In reality, Aristotle follows his teacher in most cases. In few cases, however, he argues on Plato's view in the notion of light. For example, Aristotle rejected the theory of Plato that light rays were emitted from the eyes and so on. ${ }^{25}$

It should be noted here that the Master of Illumination is a Persian and there is a deity or divine concept in Persian culture, especially in the Zoroastrianism that they believe that the Mithra is a member of the Ahuric triad, protectors of truth and justice and the source of cosmic light. Mithra, according to their doctrine, is the controller or administrator of this universe and to aid in the destruction of evil. ${ }^{26} \mathrm{He}$ is then the divine representative of the Creator on earth, and is directed to protect the righteous. ${ }^{27}$

22 See for details, Norman Melchert, The Great Conversation: A Historical introduction to Philosophy (London: McGraw Hill, 2002), $52-57$.

${ }^{23}$ Ibid., 55.

${ }^{24}$ Ibid.

${ }^{25}$ For more information on his theory of optics, see, David Bolotin, An Approach to Aristotle's Physics: With Particular Attention to the Role of His Manner of Writing (Albany: SUNY Press, 1998), 67.

26 William Malandra, An Introduction to Ancient Iranian Religion (Minneapolis: University of Minnesota Press, 1983), 138-139.

${ }^{27}$ Ibid. 
As the enemy of darkness and evil spirits, he protected soul, accompanying them to paradise, and was thus a redeemer. ${ }^{28}$ Because light is accompanied by heat, he was the promoter of vegetation and increase; he rewarded the good with prosperity and annihilated the bad. ${ }^{29}$ While he is the source of light they warship fire, The Sun. Therefore, the concept of light has a position in Persian culture as a divine deity.

This concept, obviously, is verily rejected by Suhrawardi as well as other Muslims scholars while this idea is discarded in the view of Islam. So, we can't find out that this idea influences on Suhrawardi's concept of light. The view held by some of the prominent scholars of Islamic philosophy regards Suhrawardi as a philosopher who remains essentially within the Ibn Sinā philosophical domain despite his innovations and deviations from the Peripatetic view. ${ }^{30}$ It is known to us that the philosophy of Ibn Sinā is merely influenced by the Aristotle's philosophy. Thus he is well known as peripatetic master.

Preliminarily if we examine the philosophy of Ibn Sinā, we can define that some of Suhrawardi's ideas are influenced by it, i.e. the theory of knowledge ${ }^{31}$ and so on. There is another prominent work which has been done by al-Ghazālì. In his book named Mishkāt al-Anwār (The

${ }^{28} \mathrm{Ibid}$.

${ }^{29} \mathrm{Ibid}$.

${ }^{30}$ Mehdi Amin Razavi, Suhrawardi and the School of Illumination (Surrey: Curzon Press, 1997), xvii-xviii.

${ }^{31}$ According to Ibn Sinā (d. 1037), the human intellect has neither the role nor the power to abstract the intelligible from the sensible. Humans are intellectual only potentially, and all knowledge and all recollection are emanation and an illumination which come from the Angel. Only illumination by the Angel confers upon them the ability to make from this potential a real ability to think. See for more details on the theory of knowledge in the Ibn Sinā's philosophy: Henry Corbin, History of Islamic Philosophy, trans. from French into English by Philip Sherrard (London: Kegan Pawl International with Islamic Publications for the Institute of Isma'ili Studies, 1993), 172. 
Niche for Lights), ${ }^{32}$ the light is described more than any other particular works. In the first section of this book, he considers the word 'light' itself, and its plural 'lights', as applied to physical light and light; to the eye; to the intelligence, to prophets, to supernal being and finally to Allah Himself, who is shown to be not the only source of light and of these lights, but also the only real actual light in all existence. In the second part of this book, he considers a philosophical basis for this fidelity-a fidelity which some of the bolder and more extreme mystics found illogical and unspiritual.

Here, if we compare between the concept of light in Suhrawardi's philosophy and in al-Ghazāli's illustration of light we must find out a link. The idea which is developed by the Shaykh al-Ishrāq is influenced by the al-Ghazāli's concept of light. However, the Niche of Light is discussed from the view of mystical epistemology using Qur'anic light terminology, whereas Suhrawardi, in his Philosophy of Illumination develops a truly original light ontology.

According to the above discussion, it can be said that Suhraward $\bar{i}$ accordingly is regarded as one who by drawing from various sources ${ }^{33}$ interprets Ibn Sinā, thereby synthesizing Aristotle and Plato. In real sense, the concept of light in the philosophy of Illumination is more related to the Platonic philosophy then other philosophies. However, the whole philosophy of Illumination is regarded to the peripatetic school.

Therefore, it should not be prudent to relate the origin of Suhrawardi's concept of light to the Peripatetic school, as a whole, while Suhrawardi states that the intimations,

32 For more information of the Niche for Lights, see: Al-Ghazali, Mishkat al-Anwar (the Niche for Lights), trans. W.H.T Gairdner (Lahore: SH. Muhammad Ashraf, 1952), 175.

33 For more information on the origin or the source of Suhrawardi's idea, see: S. H. Nasr, "Suhrawardi: The Master of Illumination, Gnostic and Martyr," in Islamic Philosophy and Theology, vol. 4, ed. I.R. Netton (ed.), 74-77. 
for example, is written according to the Peripatetic method, this should not be considered an independent work written about Peripatetic philosophy. Rather, it indicates that the philosophy of Illumination includes but is not defined by accepted Peripatetic teachings, parts of which Suhrawardi accepted and parts of which he rejected or refined..$^{34}$ Finally, we can mention here a statement of Suhrawardi himself to state explicitly the nature of $i s h r \bar{a} q$ wisdom and its relation to ancient doctrines. He writes:

"Although before the composition of this book

I composed several summary treatises on Aristotelian philosophy, this book differs from them and has a method peculiar to itself. All of its material has not been assembled by thought and reasoning; rather intellectual intuition, contemplation, and ascetic practices have played an important role in it. Since our sayings have not come by means of rational demonstration but by inner vision and contemplation, they can't be destroyed but the doubts and temptations of the sceptics. Whoever is a traveller (sâlik) on the way to truth is my compaction and a help on this path.... And the $i s h r \bar{a} q \bar{i}$ wisdom the foundation and basis of which are the two principles of light and darkness as established by the Persian sages.... is among these hidden, secret symbols. One must never think that the light and darkness which appear in our expressions are the same as those used by the infidel Magi

34 Hossein Ziai, "Shihab al-Din Suhrawardi: Founder of the Illuminationist School," in Islamic Philosophy and Theology, vol. 4, ed. I.R. Netton (London: Routledge, 2002), 39. 
or the heretical Manicheans for they finally involve us in idolatry (shirk) and dualism. ${ }^{35}$

The above mentioned quotation can be simply summarized in the figure below:

\section{Figure 1: Shihāb al-Dīn Suhrawardī's sources of doctrine $^{36}$}

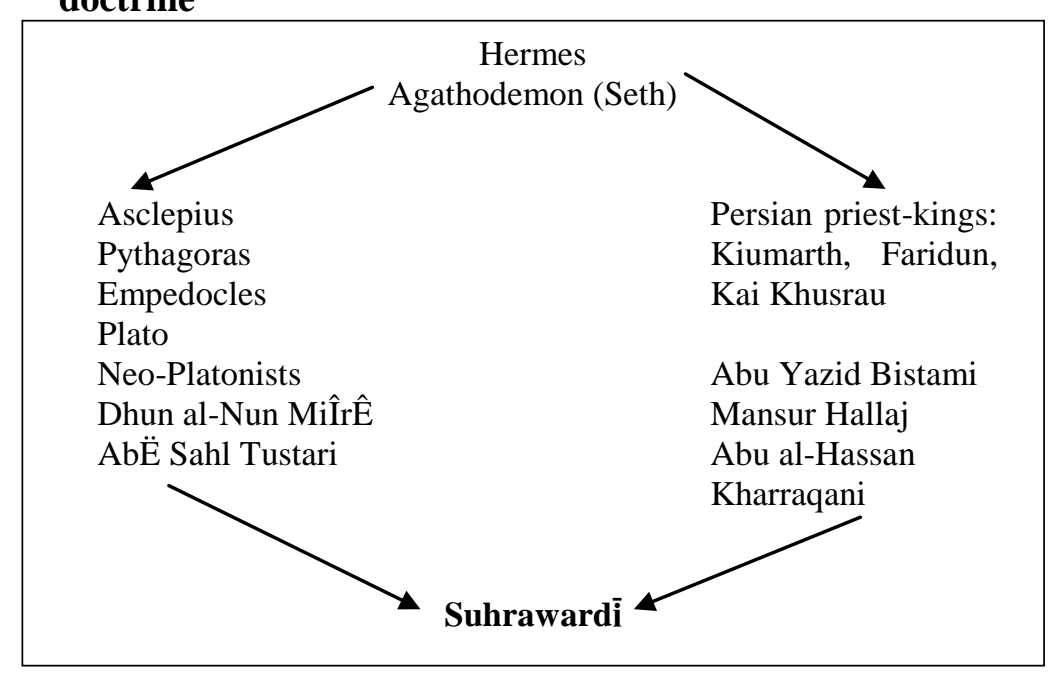

\section{Suhrawardī's Philosophical Epistemology}

The cornerstone of Suhrawardi's Ishrāqi epistemology is that any epistemological relationship can take place if, and only if, we know ourselves first. In fact, this idea can also be viewed in the contest of Socrates' thesis "know thyself". For Suhrawardi, when we say "I know P" or "I do P", we have implicitly stated that we know ourselves.

The basic Illuminationist principle is that to know something is to obtain an experience of it, tantamount to a

${ }^{35}$ Shihāb al-Dīn Suhrawardī, "Kitāb Hikmāt al-Ishrāqī," in Majmu'ah Muṣannafāt Ishrāq (Tehran: n.p., 1373 AH), 9-11.

${ }^{36}$ Nasr, Shihāb al-Dìn Suhrawardì al-Maqtūl, 376. 
primary intuition of the determinants of the thing. Therefore, the knowledge of Illuminationist is called 'knowledge by presence'. If we study Suhrawardi's works, it would be clear to us that the Ishrāqi epistemology consists of four stages. First three stages dealing with the question of knowledge while fourth stage dealing with describing the experience.

The first stage is preparing activities for accepting 'experience', the last stage. The second is the stage of illumination, in which the philosopher attains vision of a 'Divine Light'. The third stage is the stage of construction where he obtains unlimited knowledge and this is the Illuminationist knowledge or Ishrāqi knowledge. The last stage is the documentation or written form of that visionary experience. Therefore, the third and fourth stages as documented in Suhrawardi's writings are the only components of the philosophy of Illumination.

There is a way to attain this knowledge in the philosophy of Illuminationist. In the first stage, there are three things consist of; (1) an activity, ${ }^{37}$ (2) a condition, and; (3) personal 'revelation'. According to Suhrawardi, a portion of the 'light of God' resides within the philosopher, who possesses intuitive powers. Therefore, by practicing the activities in this stage, he or she is able, through 'personal revelation' and 'vision', to accept the reality of his or her own existence and admit the truth of his or her own intuition. ${ }^{38}$

Actually, first stage leads to the second, and the Divine Light enters the being of the human. This light then takes the form of a series of 'apocalyptic lights', and through them the knowledge that serves as the foundation of real sciences is obtained. In third stage, philosopher

\footnotetext{
37 Activities refer to go on a forty-day retreat, abstaining from eating meat and preparing for inspiration and 'revelation'. Suhrawardi, Opera II, 241, as cited in Ziai, Shihab al-Din Suhrawardi, 51.

${ }^{38} \mathrm{Ibid}, 52$.
} 
constructs his knowledge. Thus, it can be called this stage as 'the stage of constructing a true science'. Here, the experience is put to the test. This is accomplished through a process of analysis aimed at demonstrating the experience and constructing a system in which to place the experience and validate it, even after the experience has ended. ${ }^{39}$ The impact of the specifically Illuminationist theory of knowledge, generally known as 'knowledge by presence', has not been confined to philosophical and other specialist circled, as Illuminationist logic has been, for instance. This model involves a subject and creativity. ${ }^{40}$

In summary, we can conclude to state that the Ishrāqi epistemology is not like any other philosophy. The true knowledge can be gain by the experience with some practices which is from the 'Divine knowledge' and it is the unlimited knowledge. Specially, in the philosophy of illumination, The Light of Light controls everything, and illuminates everything. On the other hand, the Light of Light is self-emanating, and its attributes and essence are one. Thus, all abstract lights are illuminated directly by the Light of Lights, whose luminosity; essence and power are all one and the same. When the 'heavenly illuminations" reach the human soul through the intervention of the isfahbad light, all knowledge is given to the person. Such moments are the visions of the apocalyptic lights, which are the foundation of visionary experience, and means of obtaining unrestricted knowledge. It is gained in third stage.

\section{Essence and Existence}

The concept of light manages to 'disrupt' classical 'Peripatetic ontology' by somehow rendering irrelevant the Ibn Sinā distinction between essence and existence in

\footnotetext{
${ }^{39}$ See for details, Ziai, Suhrawardi, 51.

${ }^{40}$ See for details, Ibid., 52.
} 
contingent beings. ${ }^{41}$ Perhaps following Aristotle, Ibn Sīnā favored the primacy of essence over existence; the latter considered an abstract concept. Suhrawardi criticized and rejected the Peripatetic logical distinction between the two concepts, insisting that the concept of existence is added to quiddity in re, such that the general extension of the concept of existence remains a mental predicate, not a real one. For Suhrawardi, concepts such as essence and existence considered a priori and real were "merely mental considerations ( itibāri $\overline{\text { ) }}$ with no corresponding reality". ${ }^{42}$

The primacy of light signals a shift in the understanding of the very nature of the 'essence' of things. The degree or intensity of light of essences makes them distinct from one another, although they all share in the same light whose origins remain with the Light of Lights. Everything partakes in and of light, in an almost infinite manner. The distinction between essence and existence no longer becomes appropriate to assert contingency and only remains notional, since the difference between necessary and contingent beings now depends on whether a being possesses light in itself or light for other than itself. ${ }^{43}$ In his Philosophy of Illumination, Suhrawardi writes: "Light is divided into light of itself and in itself and light of itself but in another. You know that accidental light is light in another. Thus, it is not a light in itself although it is a light of itself' ${ }^{44}$

${ }^{41}$ S. H. Rizvi, "Roots of an Aporia in Later Islamic Philosophy: The Existence-Essence Distinction in the Philosophies of Avicenna and Suhrawardi," Studia Iranica, vol. 29, (2000), 61-108.

42 S. H. Rizvi, "An Islamic Subversion of the Existence-Essence Distinction? Suhrawardi's Visionary Hierarchy of Lights," Asian Philosophy, vol. 9.3, (1999), 222.

43 Ibid., 223.

44 Shams al-Din Shahrazuri, Sharh Hikmah al-Ishraq, ed. H. Ziai (Tehran: Mu'assasah-yi Mutali'at wa Tahqiqat-i Farhangi, 1993), 24. 


\section{The Relationship between God and Man in Șüfi Ishrāqi}

It is well know that the relationship between Allah and human being is the Creator and the creation. The Qur'an states: "Behold, the Lord said to the angels: I am about to create man from clay". 45 Additionally, the ultimate goal of Man is achieve pleaser of Allah to be success in this world as well as in the life after death. But what is the relationship between God and Man in the view of Süfi Ishrāqi ? Yes, the main objective of this section is to depict the relationship between God and Man according to the Șüfì Ishrāqì.

It is necessary to discuss two things if we are required to discuss the relationship between God and Man. Firstly the concept of God and secondly the concept of Man according to the view of this school.

First of all, the concept of God according to the school of Illumination is the real manifest. In this school, God is equated with the Light of Lights from whom emanate the lower levels of light, the angelic order and the archetypes. Therefore, the existence of God is fundamental for the validity of the philosophy of illumination and in particular the emanationistic scheme. There is nothing Necessary Being except He, there is no power equal to His power and there is nothing equal to Him and so on. Suhrawardi states to describe the existence of a Necessary Being and its attributes as follows:

Since there is no other Necessary Being, He has no match and because there is no force equal to Him in power and might, there is nothing to oppose Him. Since $\mathrm{He}$ has no location, He has no negation like the negation of whiteness that is black. All the power is emanated from Him and therefore nothing is His enemy. He is the Truth, meaning He exists because of His own essence and everything

45 Al-Qur'an, 36:71. 
other than His essence is not real since in their won essence they are not worthy of existence by necessity. Therefore, their truth comes from the ultimate truth and not of their own essence. ${ }^{46}$

If we refer to the Philosophy of Illumination, we can see that the God is described as the Light of Light, the source of all other lights. He is self-manifested. By demonstrating that the existence of all beings is contingent, he has also prepared the path which leads to his Ishrāqi views where he equates God with Light and Light with Being.

Finally, everything is manifested from the Light of Light, God. Nothing has the real existence except God. The man is one thing of His other creation. It is also manifested from Him. But, according to the philosophy of Illumination, man has two parts, i.e. the body and the soul. He adheres to the traditional distinction between the body and the soul. Body for him represents darkness, and absence or a lack of light to which he refers as "body" (Haykal). The soul is the Holy Spirit, which breathes into humankind the human spirit, called the 'Isfahbad of humanity' which is received because of their perfection from the Gabriel.

The ultimate return of the soul is to its original abode in the intelligible world, according to the philosophy of Illumination. For him, the final liberation of the terrestrial light from the bondage of the body in which it dwells and which it manages is contingent upon the disintegration of the body. It will be released from all the fetters which held it down and will be able to join the ranks of the 'holy spirits' which dwell in the world of pure light. Man should seek perfection to get love of Allah. The Man must return

46 Suhrawardi, Opera Metaphysica et Mystical 2 (Istanbul: Ma'rif Matbasi, 1945), 140. As quoted by Razavi, Suhrawardi and the School of Illumination, 39. 
to Allah so that he needs perfection. That is why he, Suhrawardi, states some paths to achieve perfection of human life in his book "Bustān al-Qulūb". ${ }^{47}$ And this is the practical aspects of the sufi path according to the Sufi Ishrāqi.

In summary, the relationship between God and Man is the God is the real Existence, which is the Light of Light described by Illiminationist and Man is manifested light form the source of Light, God. The body without soul is the last level of light, darkness and the soul is light which he has received with his perfection from the angel Gabriel. This is the Holy Spirit which is called 'Isfahbad of humanity' by Illuminationist. The soul must return to the world of pure light to join the ranks of the 'holy spirits'.

\section{Conclusion}

The contribution of Suhrawardi in Islamic Philosophy as well as in the history of Islamic mysticism is considered as a new distinct from the Peripatetic school. One of the foundations of the Philosophy of Illumination is that the laws governing sight and vision are based on the same rule, consisting of the existence of light. Thus, in Suhrawardi's Illuminationist philosophy, light, illumination, sight, vision, creative acts and by extension all things-may be explained through the existence of light emanated by the Light of Light. It can also be stated that it is not been possible to discuss all of his contributions to the Islamic knowledge while he has numerous works and a strong position as the master of illumination among the Muslim sages in the world, especially in Persia. Therefore, future research on his life and his philosophy should be done deeply by the researcher of comparative philosophy

47 See for details, Razavi, Suhrawardi and the School of Illumination, 71-72. 
including those who are interested to study the Islamic philosophy and Islamic mysticism.

\section{References}

Al-Ghazali. The Niche for Lights, trans. W.H.T Gairdner. Lahore: SH. Muhammad Ashraf, 1952.

Audi, Robert. The Cambridge Dictionary of Philosophy, $2^{\text {nd }}$ edn. United Kingdom: Cambridge University Press, 1999.

Borchert, Donald M., ed. Encyclopedia of Philosophy, $2^{\text {nd }}$ edn, vols. 3, 5, $6 \&$ \& . United State of America: Thomson Gale, 2006.

Buchman, David. Mishkat al-Anwar A Parallel EnglishArabic Text. United State of America: Brigham Young University Press, 1998.

Butterworth, C. E. The Political Aspects of Islamic Philosophy: Essays in Honor of Muhsin S. Mahdi. Cambridge: Harvard University Press, 1992.

Edwards, Paul, ed. Encyclopedia of Philosophy, vol. 3. New York: Macmillan Inc, 1967.

Fakhry, Majid. Islamic Philosophy, Theology and Mysticism. Oxford: Oneworld Publications, 1997.

Hariri, H. The Principles of Epistemology in Islamic Philosophy: Knowledge by Presence. New York: SUNY Press, 1992.

Hegel, G.W.F. Lectures on the History of Philosophy 1825-1826: Greek Philosophy. United Kingdom: Oxford University Press, 2006.

Kamal, M. Mulla Sadra's Transcendent Philosophy. England: Ashgate Publishing Inc, 2006.

Khan, Charles H. Plato and the Socratic Dialogue: The Philosophical Use of a Literary Form. United Kingdom: Cambridge University Press, 2004.

Melchert, Norman. The Great Conversation: A Historical Introduction to Philosophy. Canada: McGraw Hill, 2002. 
Nasr, S. H. Suhrawardi: "The Master of Illumination, Gnostic and Martyr." In Islamic Philosophy and Theology, ed. I.R. Netton, vol. 4. London: Routledge, 2002: 65-80.

Nasr, S.H. Three Muslim Sages. New York: Caravan Books, 1966.

Razavi, Mehdi Amin. Suhrawardi and the School of Illumination. Surrey: Curzon Press, 1997.

Razavi, Mehdi Amin. "The Significance of Suhrawardi's Persian Sufi Writings in the Philosophy of Illumination." In The Heritage of Sufism: Classical Persian Sufism from its Origins to Rumi (700-1300), ed. Leonard Lewisohn, vol. 1. Oxford: Oneworld Publications, 1999: 258-282.

Shahrazuri. Sharh Hikmah al-Ishrāq, ed. H. Ziai. Tehran: Mu'assasah-yi Mutali'at wa Tahqiqat-i Farhangi, 1993.

Suhrawardī, Shihāb al-Dīn Yahya. Opera Metaphysica et Mystica III, ed. S. H. Nasr. Tehran: Mu'assasah-yi Mutali'at wa Tahqiqat-i Farhangi, 1993.

Suhrawardī, Shihāb al-Dīn Yahya. Hikmah al-Ishrāq, trans. Sayyid Ja far Sajjadi. Tehran: Tehran University Press, 1978.

Walbridge, J. The Leaven of the Ancients: Suhrawardi and the Heritage of the Greeks. Albany: State University of New York Press, 2000.

Watt, Stephen. Introduction: The Theory of Forms. London: Wordsworth Publication, 1997.

Ziai, Hossein. "Shihab al-Din Suhrawardi: Founder of the Illuminationist School." In Islamic Philosophy and Theosophy, ed. I.R. Netton, vol. 4. London: Routledge, 2002: 36-64. 